\title{
MEMAHAMI INTERIOR SEBAGAI PENGHUBUNG
}

\author{
Diana Thamrin \\ Program Studi Desain Interior, Fakultas Seni dan Desain, Universitas Kristen Petra \\ J1. Siwalankerto 121-131, Surabaya \\ Email: dianath@petra.ac.id
}

\begin{abstract}
Abstrak
Desain interior merupakan ilmu yang sangat dekat dengan kebutuhan dan kompleksitas kehidupan manusia. Namun, karena latar belakang cikal bakalnya profesi desainer interior sebagai ahli dekorasi dan pengisi ruang, serta istilah "interior" yang secara harafiah sering diartikan sebagai "ruang dalam", pemaknaan dan praktik desain interior seringkali menjadi sangat terbatas pada pengisi atau dekorasi di dalam batasan fisik yang telah terbentuk oleh arsitektur. Tulisan ini bertujuan untuk mengubah persepsi dan pandangan umum tentang konsep interior, yaitu sebagai "penghubung," atau penjembatan bersama dengan arsitektur yang sangat penting antara manusia dan lingkungan hidupnya, sehingga metode dan kreativitas dalam praktik desain interior maupun arsitektur bisa lebih kreatif dari apa yang seringkali terjadi saat ini. Tulisan ini merupakan hasil penelitian kualitatif dengan metode kepustakaan dan studi kasus. Hasil pembahasan merujuk kepada beberapa metode atau teknik pengolahan interior dan arsitektur yang dapat digunakan dalam praktik desain dengan konsep interior sebagai "penghubung," yaitu: mengaburkan batas fisik, manipulasi programatik, inovasi kontinuitas material dan konfigurasi elemen arsitektur menjadi elemen interior. Dengan memanipulasi ruang secara fisik maupun konseptual, lingkup desain interior tidak lagi menjadi sekedar pengisi ruang dan juga tidak terbatasi oleh lingkup arsitektur tetapi merupakan ilmu yang memiliki peran yang sangat penting bersama arsitektur dalam menghubungkan manusia dengan lingkungan hidupnya.
\end{abstract}

Kata kunci: desain interior, arsitektur, penghubung, pengisi, teritori interior

\begin{abstract}
Title: Understanding Interior as a Connector

Interior design is a discipline that is very close to the complexities and the needs of human life. However, the intepretation and practice of interior design are often limited to decoration and contents within the physical boundaries of architecture. This paper aims to provide another perspective regarding the concept of interior that is, as a significant connector between humans and their living environment along with architecture, so that the methods and practice of interior design as well as architecture may expand more than what has been observed today. The paper is a result of a qualitative research through literature review and exploration of case studies. Results conclude to several interior and architectural design techniques based on the perception of interior as a "connector" that could be used, such as the blurring of physical boundaries, programmatic manipulation, innovation of material continuity and configuration of architectural elements into interior elements. Through the physical as well as conceptual manipulation of space, the intepretation of interior design would no longer be limited to the contents within the physical boundaries of architecture but rather a truly important connector along with architecture, between humans and their living environment.
\end{abstract}

Keywords: interior design, architecture, connector, containment, interior territory 


\section{Pendahuluan}

Di masa lalu, ilmu desain interior terlahir dalam proses perkembangan kompleksitas lingkup ilmu arsitektur. Dari jaman Klasik hingga ke Renaissance, pekerjaan interior dilakukan oleh para arsitek sekaligus seniman. Seiring dengan berkembangnya gaya desain di Eropa, para pimpinan negara maupun arsitekarsitek bangunan mendatangkan lebih banyak seniman, pelukis atau pemahat untuk memberikan masukan mengenai kesan artistik dan dekorasi ruangan yang diaplikasikan ke permukaan elemen pembentuk ruang, elemen struktural dan elemen pengisi ruang seperti perabot dan aksesoris lainnya. Hal ini melahirkan profesi desainer interior yang menjadi sangat populer di jaman Eklektik pada akhir abad 19 (Pile, 2005). Pada jaman tersebut, desainer-desainer interior gemar mencampur dan memadukan berbagai macam elemen gaya desain. Desainerdesainer interior ternama seperti Elsie de Wolfe dan Ruby Ross Wood sering mengambil unsur-unsur dekoratif dari gaya-gaya revival Inggris seperti gaya Victorian, yang terlihat mewah dan elegan, untuk dekorasi interior rumah tinggal. Teknik mencampur dan memadukan elemen-elemen gaya desain demikian menjadi teknik yang dicontoh dan dikuasai oleh desainerdesainer interior selanjutnya. Memasuki era modern, desainer interior yang dahulu berperan sebagai pengisi dan dekorasi ruang banyak yang juga beralih ke desain produk interior seperti furniture dan alat rumah tangga untuk berusaha menciptakan produk massal yang ergonomis dan fungsional. Dengan adanya latar belakang sejarah desain interior yang demikian maupun istilah "interior" yang secarah harafiah memiliki arti "ruang dalam", peran desain interior sebagai ilmu maupun sebagai profesi hingga saat ini seringkali diartikan sebagai ahli seni dekorasi dan "pengisi" di dalam ruang dalam yang memainkan perannya setelah terbentuknya kerangka ruang oleh arsitektur. Karena persepsi umum inilah, rana desain interior seringkali dianggap tidak berarti dan inferior bila dibandingkan dengan kualitas ruang maupun fungsi yang dibentuk dahulu oleh arsitektur (Smith, 2004: 98).

Berangkat dari latar belakang diatas, tulisan ini bertujuan untuk memberikan pandangan lain mengenai peran desain interior bersama arsitektur, yaitu sebagai "penghubung" yang sangat penting antara manusia dan lingkungan hidupnya daripada sekedar "pengisi" atau dekorasi ruang dalam. Tulisan ini juga diharapkan mampu memberikan panduan aplikasi desain interior dan arsitektur dengan pemahaman interior sebagai "penghubung", sehingga praktik desain dapat lebih kreatif dari kecenderungan yang ditemukan di lapangan saat ini, di mana rana desain interior bekerja terpisah dari arsitektur sehingga mengabaikan potensi lingkungan sekitar yang ada.

\section{Metode Penelitian}

Naskah ini menggunakan metode penelitian kualitatif melalui kajian pustaka dan eksplorasi studi kasus (Moloeng, 2013). Pembahasan akan dimulai dari eksplorasi kepustakaan berisi teori-teori mengenai teritori interior, yang mendukung pandangan interior sebagai "penghubung." Kajian teori dilakukan melalui analisis deskriptif yang hasil eksplorasinya kemudian disimpulkan ke dalam sebuah panduan teknik pengolahan interior dan arsitektur yang dapat 
digunakan dalam praktik desain interior maupun arsitektur dengan pemahaman interior sebagai "penghubung." Teknikteknik pengolahan desain yang ditemukan dari hasil analisis juga akan didukung dengan eksplorasi studi kasus proyek-proyek desain dari manca negara untuk memberikan contohcontoh aplikatif dari kesimpulan tersebut.

\section{Kajian Teori}

\section{Pemahaman Interior sebagai Penghubung}

Dalam beberapa tahun ini, para kritikus desain di negara Barat mulai menganggap bahwa desain interior adalah suatu bidang ilmu yang sulit untuk didefinisikan secara spesifik karena bisa mencakup dasar teori dari sumber-sumber di luar batasan ilmu seni, desain maupun arsitektur. Salah satu dari beberapa hasil perdebatan yang disepakati saat ini adalah adanya sebuah pengertian bahwa ilmu desain interior memiliki ruang lingkup yang dapat ditembus seiring dengan berkembangnya kompleksitas lingkungan hidup manusia (Cys, 2009: 20-21). Dalam topik bahasan mengenai teritori interior, dualisme antara luar dan dalam seringkali menjadi topik yang berpolemik antara bagian mana yang merupakan peran arsitektur dan bagian mana adalah peran desainer interior. Meresponi hal ini, Grosz (2001) menggambarkan sebuah bangunan bagaikan tubuh manusia, dan batasan dari luar dan dalam tersebut sebagai kulit manusia yang menjadi loci atau pusat terjadinya pertukaran antara kondisi luar dan dalam: sebuah titik terjadinya konversi dari partikelpartikel yang saling berinteraksi dan beradaptasi dalam proses biologis. Perubahan kondisi di luar kulit tersebut akan mempengaruhi kondisi yang ada di dalamnya. Maka dalam pengertian ini, batasan antara luar dan dalam sebuah bangunan bagaikan kulit tubuh manusia yang berperan untuk membawa potensi dan meregenerasi polaritas. Berangkat dari pemahaman ini, desainer interior maupun arsitektur, seharusnya memahami batasan antara luar dan dalam bukan sebagai pemisah antara dua dunia melainkan sebagai jembatan di mana terjadinya proses adaptasi antara satu kondisi dengan yang lain. Oleh sebab itu, pekerjaan interior tidak dapat hanya berperan sebagai "pengisi" tanpa menghiraukan struktur dan lingkup arsitektur maupun kondisi luar ruangan, begitupun sebaliknya. Peran desain interior maupun arsitektur adalah bagaimana "menghubungkan," sehingga manusia dapat berdaptasi terhadap lingkungan di luarnya, bukan memisahkan dirinya dari dunia sekitarnya. Mendukung penafsiran ini, Whiton dan Abercombie (2002: 3) juga mengatakan bahwa arsitektur dan interior secara ilmu dan praktik seringkali harus menemukan cara untuk berhubungan antara satu dan yang lain sehingga hasil keseluruhan memiliki koherensi daripada saling bertentangan. Bagian mana yang harus dipikirkan dulu atau siapa yang harus mendominasi kolaborasi ini adalah pertanyaan-pertanyaan yang harus ditentukan berdasarkan kondisi dan talenta spesifik dengan tidak menutup kemungkinan adanya pengembangan atau pelintasan antara kedua ilmu masing-masing di dalam praktiknya.

Caan (2011: 32) juga berpendapat bahwa peran interior dalam mendekorasi dan mengisi bukan untuk menciptakan sebuah lingkungan eksklusif dari dunia luar, melainkan sebuah jembatan antara realitas dunia dan kondisi ideal yang dibutuhkan oleh 
penggunanya. Sebagai contoh, lukisan maupun relik yang digambarkan manusia purba kala di dalam dindingdinding gua di masa lalu adalah sebuah upaya untuk menghubungkan mereka ke dunia alam. Dalam pemahaman ini, maka isi dan dekorasi dalam interior merupakan zona maupun media transisi yang membantu serta mendukung manusia untuk menghadapi kondisi nyata lingkungan di dunia sekitarnya.

Dengan pemahaman yang serupa, Smith (2004) mendefinisikan interior sebagai "betweeness and blurring" daripada sebagai pengisi di dalam sebuah wadah tertutup. Dalam penerjemahan harafiah, "betweeness" dapat diartikan sebagai "di antara" atau sebuah kualitas yang berada di posisi tengah, sedangkan "blurring" berarti sebuah kondisi yang kabur. Artinya, interior tidak seharusnya dipahami sebagai suatu batas fisik konkrit untuk memisahkan dua dunia yang memiliki kualitas yang saling bertentangan melainkan seharusnya berperan untuk mengaburkan batas tersebut sehingga terjadi sebuah hubungan antara manusia dan lingkungan. Interior bukanlah bagian isi di dalam sebuah kerangka melainkan berperan mendukung terciptanya kerangka di mana manusia dapat beradaptasi dengan lingkungan sekitarnya.

Dari kajian teori mengenai teritori interior ini, maka dapat disimpulkan bahwa hampir semua kritikus yang telah dibahas memaknai interior bukan sebagai sekedar pengisi ruang yang telah dibentuk dahulu oleh kerangka arsitektur, ataupun tukang seni dan ahli dekorasi, tetapi memiliki sebuah peran yang jauh lebih penting, yaitu menghubungkan manusia dengan lingkungan hidupnya. Di dalam sejarah perubahan lingkungan dan perkembangan kompleksitas kehidupan manusia, mereka berupaya untuk mencari kebenaran dengan mengkaitkan segala sesuatu dan sering menemukan keterkatian antara suatu fenomena alam dengan fenomena yang lain. Menyimak hal ini, maka perbedaan berdasarkan oposisi biner antara besar dan kecil, dekat dan jauh atau luar dan dalam, sebenarnya saling terkait. Sesuai dengan pemahaman ini, Pimlot (2009: 93) beranggapan bahwa selama ini, ambisi desainer interior cenderung berupaya mengisi segala sesuatu dan mengganggap hal-hal di luar itu tidak penting. Menurutnya, sesungguhnya semua aktivitas maupun kebutuhan manusia itu saling berinterkonseksi, dan desain bangunan untuk manusia di jaman ini seharusnya dapat menghubungkan semua aspek kehidupannya dengan tempat ia beraktivitas sehingga manusia tidak perlu lagi secara konkrit memisahkan antara rumah dan kantor, mobil dan rumah, airport dan mall dan sebagainya. Sebagai contoh, konsep ruang transisional seperti karya Mobius House oleh UN Studio (Gambar 1) yang olah ruangnya didesain berdasarkan transisi aktivitas pengguna sehari-hari dan potensi serta keragaman pola geografis di lingkungan sekitar, merupakan konsep desain bangunan yang mengikuti perkembangan kompleksitas kehidupan manusia di mana semua aspek hidupnya saling terkait dengan tempat ia beraktivitas, mendukung pendapat dari Pimlot (2009).

Oleh sebab itu, peran desain interior maupun arsitektur yang begitu dekat dengan manusia seharusnya mengikuti berkembangnya pola kehidupan manusia yang berusaha mengeksplorasi banyak kemungkinan dari kenyataan di dunia ia beraktivitas dengan tidak membatasi diri di dalam ruang tertutup 
tanpa memperdulikan apa yang terjadi di luar lingkup satu bidang tertentu.

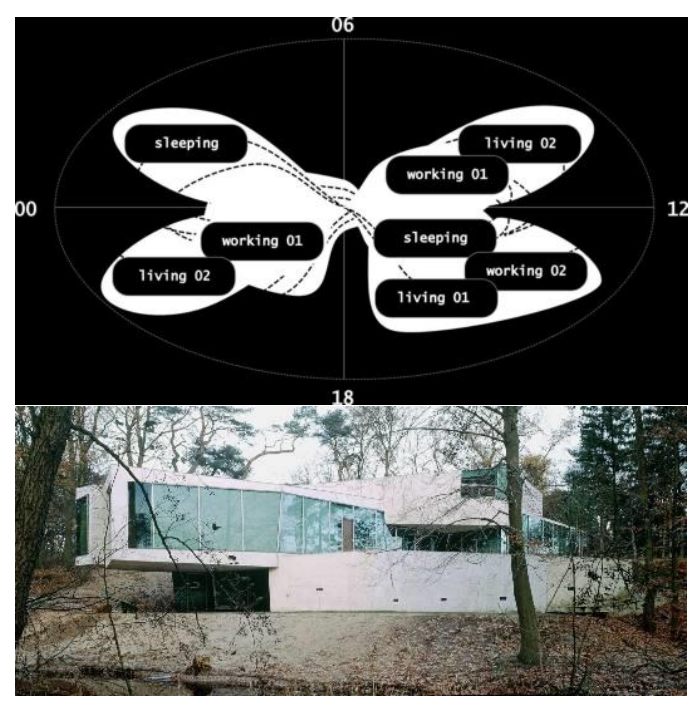

Gambar 1. Konsep ruang transisional yang mengikuti bentuk mobius stripe loop. Bangunan ini didesain berdasarkan transisi aktivitas sehari-hari serta respon terhadap beragam kualitas spasial lingkungan sekitar. Sumber: http://architizer.com/projects/mobiushousel, diunduh 29 November 2016

Dalam pengertian ini, maka desainer interior maupun arsitek yang baik harus berusaha kreatif untuk menjembati dan menghubungkan manusia dengan potensi lingkungan manusia secara geografis maupun secara sosial melalui semua karya desainnya.

\section{Teknik Olah Desain dengan \\ Pemahaman Interior sebagai Penghubung}

Tulisan selanjutnya akan membahas kajian teori teritori interior yang telah diuraikan diatas yang dapat merujuk pada beberapa teknik pengolahan desain interior dan arsitektur dengan pemahaman interior sebagai "penghubung." Ada empat teknik pengolahan desain yang dapat disimpulkan untuk mendukung praktik pemahaman interior sebagai "penghubung" yang sangat penting antara manusia dan lingkungannya.

\section{Mengaburkan Batas Fisik}

Tulisan Grosz (2001) mengenai kulit dan loci menggambarkan bahwa elemen pembentuk ruang seharusnya bukan berfungsi sebagai batas konkrit secara fisik yang memisahkan antara luar dan dalam, melainkan sebuah membran dimana terjadi sebuah proses adaptasi antara lingkungan satu dengan yang lain. Mendukung hal ini, istilah "blurring" yang disebutkan oleh Smith (2004) untuk mendefinisikan interior juga dapat diaplikasikan pada batas fisik antara interior dan eksterior dengan cara mengaburkan batas tersebut. Ada beberapa contoh kasus proyek yang pernah didesain dengan teknik pengaburan batas fisik. The Bridge School (gambar 2) merupakan sebuah sekolah di daerah pedesaan di area kaki gunung yang terletak di antara rumah-rumah tradisional Fujian, China yang dimanakan tulou.

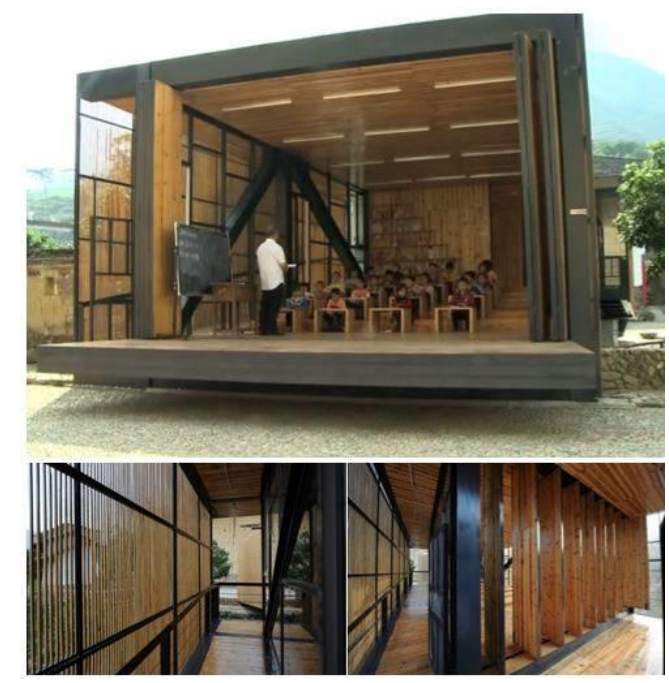

Gambar 2. Pengaburan batas fisik dalam rancangan The Bridge School di Fujian, China

Sumber: http://www.archdaily.com/45409/schoolbridge-xiaodong-li/, diunduh 3 November 2014

Tujuan desain ini adalah adanya keinginan untuk memunculkan kembali komunitas lokalnya dan mempertahankan karakter situsnya 
dengan cara menghubungkan aktivitas ajar-mengajar dengan lingkungan sekitarnya. Dengan menggunakan partisi yang dapat di buka sepenuhnya dan menggunakan screen dari batangbatang kayu setempat, tidak ada batas fisik yang jelas antara luar dan dalam sehingga pengguna tetap bisa merasakan suasana desa mereka saat beraktivitas. Potensi lingkungan sekitar digunakan untuk mendukung kegiatan ajar-mengajar dengan mengaburkan batas antara luar dan dalam.

Proyek serupa dengan yang di atas adalah sebuah kantor dan tempat istirahat pengelola sebuah situs alami. Proyek ini juga terletak di sebuah pegunungan di pinggiran kota Ningbo di China (gambar 3). Untuk menciptakan kesan komunitasnya, ruang-ruang dipotong untuk menghadap ke dua area courtyard atau halaman tengah yang merupakan elemen ciri khas bangunan tradisional China. Untuk menyatukan area courtyard dan pemandangan pegunungan yang indah dengan program ruang, bangunan tidak dibatasi dengan dinding, melainkan memainkan elemen tabir dengan menggunakan material kayu lokal dan bambu setempat. Elemen ini mengaburkan batas fisik sehingga koneksi programmatik tercipta dengan memberikan kontinuitas antara ruang dan dengan area luar yang dapat ditembus secara visual daripada membuatnya terpisah. Konsep ini identik dengan konsep pemahaman ruang budaya China, dimana terjadi pengalaman ruang yang beralur dan menembus dari satu bagian dengan yang lain. Maka dari studi kasus ini, pengolahan elemen interior tidak lagi berfungsi sebagai pengisi, tetapi menghubungkan aktivitas manusia dengan potensi lingkungan sekitarnya dengan cara mengaburkan batas fisik.

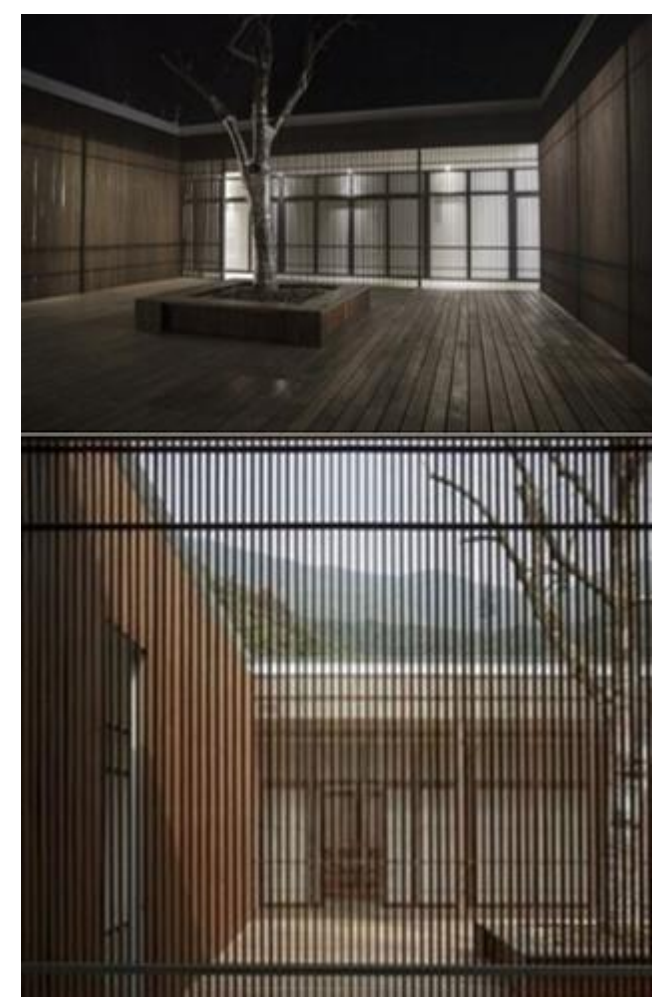

Gambar 3. Pengaburan batas antara interior, courtyard dan pemandangan alam dengan menggunakan tabir bambu Sumber: http://www.archdaily.com/494802/thescreen-li-xiaodong-atelier/, diunduh 3 November 2014

\section{Manipulasi Programatik}

Proyek penggunaan tabir bambu di atas juga menunjukan sebuah teknik olah desain dengan pemahaman interior sebagai penghubung, yaitu teknik manipulasi programmatik. Seperti pendapat Pimlot (2009), peran interior maupun arsitektur adalah untuk mengakomodasi pola berkembangnya aktivitas manusia yang saling terkait dengan yang lain sehingga tidak harus ada batas fisik yang konkrit antara satu tempat dengan yang lain. Salah satu contoh aplikasi dari pemahaman tersebut adalah proyek The New Kyoto House oleh Kentaro Takeguchi dan Asako Yamamoto, yaitu sebuah rumah tinggal yang terletak di daerah yang 
sangat sempit di Kyoto (gambar 4). Karakter yang paling unik dari rumah tersebut adalah bentuk polyhedral pada dinding-dinding partisinya. Elemenelemen tersebut dirancang berdasarkan konsep dan performa multi-fungsi dari penggunanya.

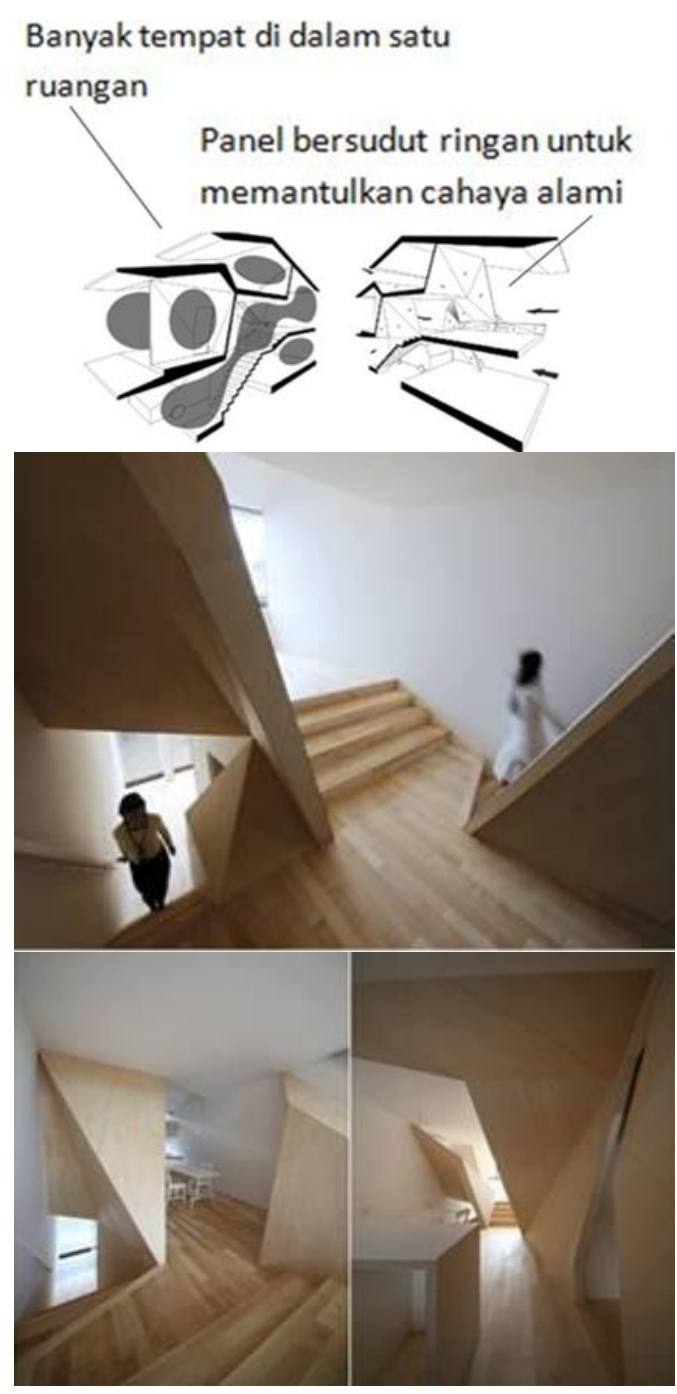

Gambar 4. Skema manipulasi programatik pada desain rumah tinggal New Kyoto House melalui dinding bersudut irregular menunjukkan aplikasi pemahaman interior sebagai penghubung antara manusia, aktivitas dan potensi lingkungannya

Sumber: diolah oleh penulis dari http://www.designboom.com/architecture/alphavill e-new-kyoto-house/ , diunduh 3 November 2014
Dinding tidak didesain secara lurus ke arah vertikal dan horizontal seperti pada umumnya tetapi mimiliki dimensi berkelipatan dan menghubungkan ruang-ruang secara longgar di semua lantai yang berjumlah tiga itu. Ruang yang tercipta dari pengolahan interior dan arsitektur ini adalah satu ruang yang berkelanjutan dengan pengalaman ruang yang dinamis, luas dan sekaligus heterogen. Aktivitas di rumah tersebut menjadi lebih fleksibel karena pengolahan ruang mendukung kegiatan mulit-fungsi serta berhasil menghubungkan beragam aktivitas dinamis manusia di dalam satu tempat.

Bersamaan dengan teknik manipulasi programmatik, partisi-partisi tersebut juga berperan dalam mengaburkan elemen pembentuk ruang dengan perabot sehingga bersama-sama menstimulasi persepsi dan perilaku penggunanya. Selain itu, dalam pemahaman interior sebagai penghubung, peran interior juga sedapatnya berusaha bersama-sama dengan arsitekturnya menggali potensi lingkungan sekitar dan membuat manusia di dalamnya beradaptasi sehingga mendapatkan manfaat dari lingkungan sekitar. Berkaitan dengan pemahaman ini, dinding-dinding yang bersudut ireguler tersebut yang memungkinkan pembukaan yang lebar pada dinding dan lantai juga berfungsi sebagai reflektor cahaya alami dari utara dan selatan. Hal ini untuk menerangi ruang-ruangannya, yang seharusnya gelap bila menggunakan dinding-dinging tegak lurus karena lokasi rumahnya yang rapat dengan bangunan lain. Komunikasi dan pergerakan secara tiga dimensi antara sesama manusia maupun dengan lingkungannya tercipta karena berhasilnya pengolahan interior dan arsitektur yang berusaha untuk 
menghubungkan segala sesuatu baik secara intrinsik maupun ekstrinsik.

Dengan memanipulasi program ruang serta mengaburkan batas, desain interior dapat berperan bersama arsitektur dengan baik sebagai penghubung antara manusia, aktivitas dan lingkungannya daripada hanya sekedar pengisi ruang.

\section{Inovasi Kontinuitas Material}

Berkaitan dengan teknik pengaburan batas yang telah dibahas sebelumnya, penggunaan material juga dapat menjadi teknik yang berperan dalam praktik pemahaman interior sebagai penghubung. Berangkat dari pemahaman Caan (2011: 32) bahwa peran interior dalam mendekorasi dan mengisi bukan untuk menciptakan sebuah lingkungan eksklusif dari dunia, melainkan sebuah jembatan antara realitas dunia dan kondisi ideal yang dibutuhkan oleh penggunanya, maka dekorasi dan isi yang dipilih oleh desainer interior maupun arsitektur juga patut dipikirkan sebagai media penghubung antara manusia dengan lingkungannya. Dalam hal ini, pemilihan dan inovasi penggunaan material dapat dijadikan elemen yang diolah untuk tujuan tersebut. Sebelum terbentuknya produk bahan interior yang diproduksi secara masal di era modern, bahan-bahan alam diolah dengan tangan atau hand-made untuk diaplikasikan pada bangunan eksterior maupun interior. Tidak ada perbedaan ekstrim secara visual dan nuansa antara ruang interior dan lingkungan luar sehingga manusia tetap berhubungan dengan kondisi sekitar dan memanfaatkan potensi alam yang ada untuk dinikmati bersamaan dengan aktivitas mereka sehari-hari. Namun, dewasa ini, kepraktisan dan effisiensi yang dihasilkan oleh produk-produk masal interior membuat desainer interior maupun penggunannya sibuk dalam mengisi ruang dalam mereka dengan produk-produk yang memberi kenyamanan instan sehingga mereka telah membangun tembok yang solid dan menutup diri dari potensi lingkungan alam sekitar. Belajar dari sejarah, ada beberapa arsitek dunia di masa lampau yang tidak pernah mengganggap harus adanya pembedaan yang ekstrim antara lingkungan eksterior dan interior, mendukung pemahaman Caan (2011). Semua bangunan didesain dengan pola pikir dan konsep yang menyeluruh antara ekterior dan interior dimana pengolahan interior, tertuama dalam hal material dan penataan ruang dirancang untuk beradaptasi dengan alam sekitar. Karya Falling Water dari Frank Llyod Wright (gambar 5) merupakan sebuah rumah tinggal yang begitu terkenal karena berhasil membuat perancangan yang dapat begitu menyatu dengan potensi alamnya.

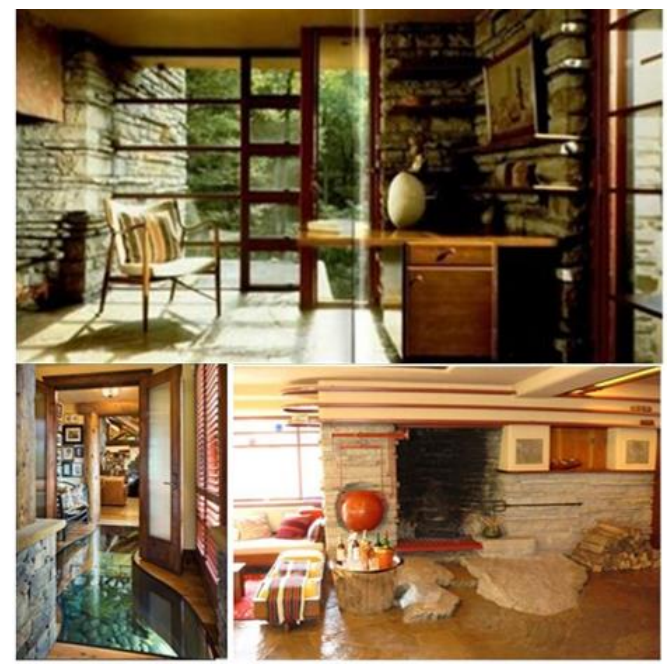

Gambar 5. Inovasi kontinuitas material lingkungan eksternal ke dalam interior merupakan salah satu teknik penting yang digunakan oleh Wright untuk menghubungkan aktivitas manusia dengan potensi lingkungan sekitar Sumber: http://imgkid.com/falling-water-interiorstream., diunduh 5 Novermber 2014 
Salah satu teknik penting yang Wright gunakan dalam pengolahan interior dan arsitektur adalah penggunaan material setempat sehingga tercipta sebuah kesatuan antara manusia yang beraktivitas di dalamnya dan lingkungan yang memberikan suasana yang menyenangkan secara psikologis. Wright mengambil batu-batu kali yang diambil langsung dari lokasi air terjun di mana rumah tersebut ditempatkan dan menggunakannya untuk lantai, dinding, perabot dan elemen perapian sehingga suasana alam sekitar tetap dapat dirasakan oleh pengguna saat beraktivitas di dalam rumah. Inovasi kontinuitas material ini berperan dalam mengaburkan batas antara interior dan eksterior dan berhasil mengakomodasi manusia untuk dapat beradaptasi dan berinteraksi dengan lingkungannya, sesuai dengan makna peran interior yang seseungguhnya menurut Caan (2011).

\section{Konfigurasi Elemen Arsitektur menjadi Elemen Interior}

Berangkat dari pendapat Whiton et.al (2002) tentang pentingnya koherensi antara arsitektur dan interior, maka peran desainer interior bukan hanya sebagai pengisi ruang, tetapi bagaimana interior dapat mendukung konsep keseluruhan dari arsitekturnya sehingga lebih efektif menghubungkan aktivitas manusia dengan lingkungannya. Elemen arsitektur dan interior harus bekerjasama untuk saling melengkapi dalam memwujudkan tujuan yang sama yaitu memampukan manusia hidup dan beraktivitas di lingkungan sekitarnya. Namun, yang sering terjadi di dalam perancangan bangunan modern saat ini adalah ketidak-selarasan antara elemen interior dengan konsep bangunan arsitekturnya sehingga terciptalah sebuah ruang eksklusif dan tertutup dari semua potensi bangunan yang telah dirancang di awal. Sebagai bentuk aplikasi dari teori Smith (2004) tentang "betweeness" dan "blurring," interior dapat berperan untuk mendukung potensi arsitektur dan lingkungannya dengan cara memanfaatkan elemen arsitektur menjadi elemen interior. Dalam pengertian ini, maka pengolahan desain dapat mengaburkan batas antara elemen arsitektur dan interior sehingga tercipta sebuah kesatuan ruang secara fisik maupun konseptual. Elemen arsitektur yang dapat dijadikan obyek interior bisa meliputi kolom, balok dan elemen struktur bangunan maupun potensi view yang ada disekitarnya. Sebagai salah contoh yang paling kuno, di dalam konsep bangunan tradisional China, sebuah bangunan dirancang dengan memperhatikan baik posisi lokasi bangunan sehingga dapat mendukung esensi yang paling penting dalam keharmonisan hidup manusia menurut kosmologi orang China, yaitu terpeliharanya hubungan baik antara manusia dengan alam (Li dan Yang, 2010). Di jaman dahulu, bangunan dirancang di area-area spesifik di antara taman-taman yang dihias dengan indah, seringkali dengan air, batubatuan dan tanaman-tanaman yang memiliki makna-makna spiritual (Lou, 2010). Detail-detail elemen bangunan diperhatikan dan dirancang dengan sangat teliti dari dimensi, bentuk, warna maupun posisinya. Dinding, jendela dan pintu pada bangunanbangunan tersebut tidak berfungsi sebagai sekedar pembatas, melainkan sebagai elemen yang mengatur hubungan manusia dengan alam. Pengaturan letak jendela dan perabot ruangan tidak dilakukan hanya berdasarkan pola aktivitas manusia, namun didesain untuk merespon kondisi lingkungan di luar. 

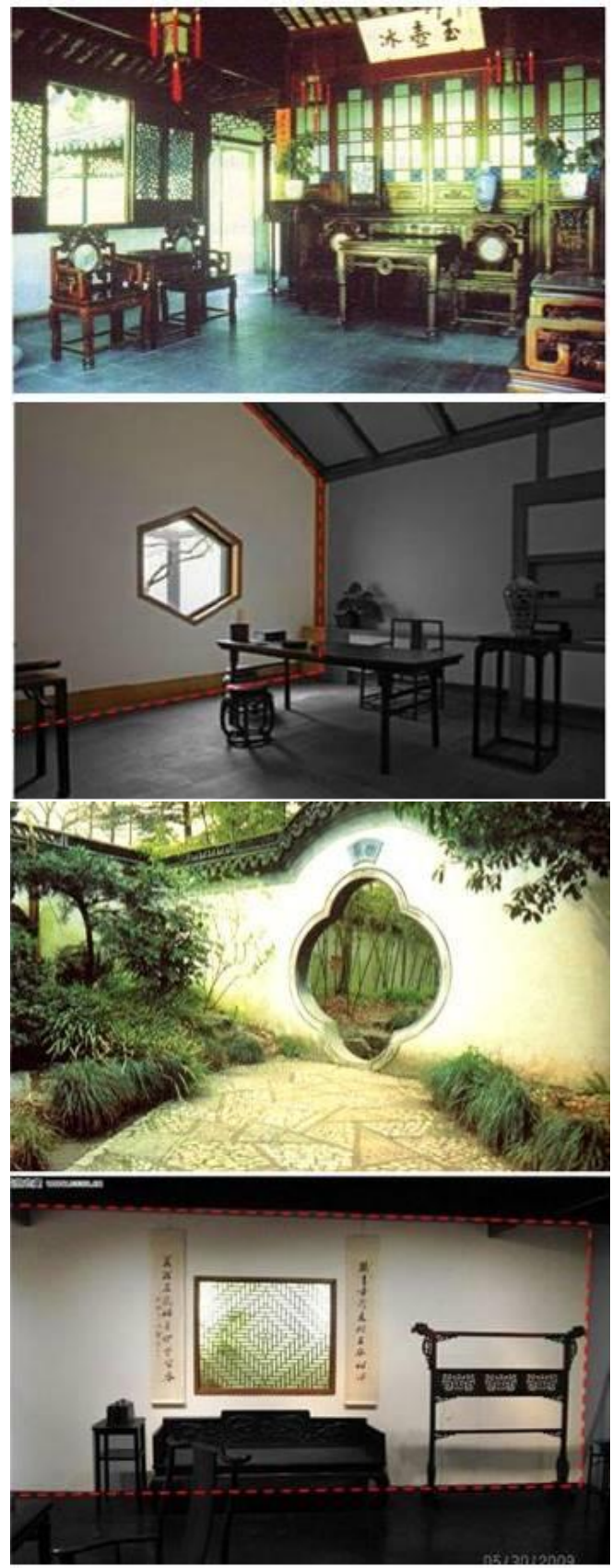

Gambar 6. Elemen dinding, jendela dan pintu berfungsi untuk mengatur hubungan manusia dengan alam dalam bangunan tradisional China

Sumber: Olahan Penulis dari Lou, 2010: 63, 69 dan http://www.shme.com/travel/museum/museum.htm, diunduh 5 November 2014

Di dalam pengaturan interior tersebut, terutama di area shufang atau ruang kerja, yang merupakan ruang privat di mana bangsawan terpelajar berkontemplasi dan mencari inspirasi, seringkali terdapat sebuah bukaan di dinding yang bisa berupa jendela ataupun bukaan dengan bentuk tertentu yang sengaja membingkai, menyaring atau memusatkan pandangan ke sebuah pemandangan tertentu dari area luar (Gambar 6). Bukaan ini dirancang secara khusus dari segi bentuk, dimensi, bahan dan warna dan secara strategis menyatu dengan letak elemenelemen perabot dan aksesoris di dalam ruangannya. Elemen desain ini dikenal dengan istilah "borrowed scenery" yang berarti peminjaman pemandangan (Cai, 2010: 126).

Pengaturan elemen-elemen eksterior dijadikan elemen interior dan sebaliknya sehingga bekerjasama untuk menciptakan sebuah pengalaman ruang bagi manusia. Pengaturan seperti ini menyatukan manusia dengan alam sebagai suatu hubungan yang dianggap sangat penting di dalam upaya manusia mencari inspirasi, kebenaran, ketenangan dan nilai-nilai spiritual, menurut kosmologi budaya China.

Contoh kasus konfigurasi elemen arsitektur menjadi elemen interior yang lain adalah rumah tinggal Final Wooden House di Jepang, karya Fujimoto (Gambar 7). Fujimoto menggunakan balok-balok kayu yang besar yang merupakan struktur lantai, dinding dan atap tetapi diperlebar kedalam ruangan sehingga sekaligus menjadi perabot dan tangga di dalam rumah tersebut. Bukaan jendela dan pintu terjadi pada rongga diantara balok-balok tersebut. Dalam desain ini, potensi dan nilai konseptual elemen arsitektur dijadikan obyek dari pengaturan interior sehingga bekerjasama mendukung interaksi antar manusia dengan lingkungannya. 

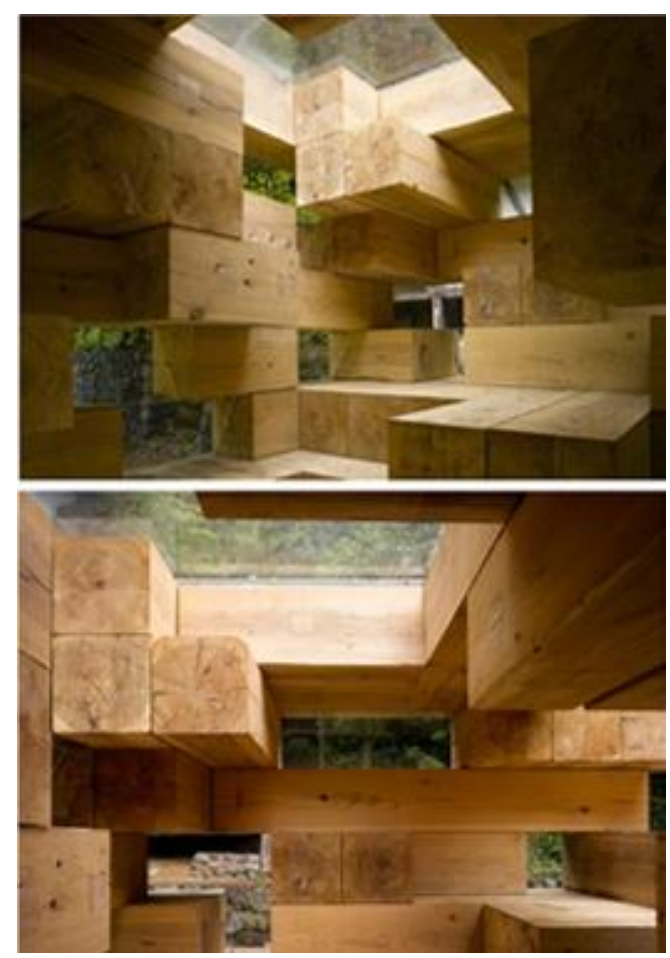

Gambar 7. Elemen arsitektur balok-balok kayu dijadikan elemen interior yang sekaligus berfungsi sebagai tangga dan perabot dalam karya Final Wooden House oleh Fujimoto.

Sumber:

http://www.dezeen.com/2013/10/28/movie-soufujimoto-sctructures-between-nature-architecture /, diunduh 10 November 2014

The Bridge School, proyek desain yang pernah dibahas sebelumnya dapat sekali lagi dijadikan contoh kasus dari aplikasi konfigurasi elemen arsitektur menjadi elemen interior. Selain berhasil mengaburkan batas antara luar dan dalam, fasad dari bangunan tersebut juga diolah sedemikian rupa sehingga menjadi fasilitas tangga dan mainan untuk mendukung kegiatan bermain dan interaksi antar anak-anak desa di sekolah tersebut (gambar 8). Akibatnya, kegiatan ajar-mengajar dan bermain di dalam maupun di luar berhasil dihubungan secara komunikasi dan pengalaman spasial.

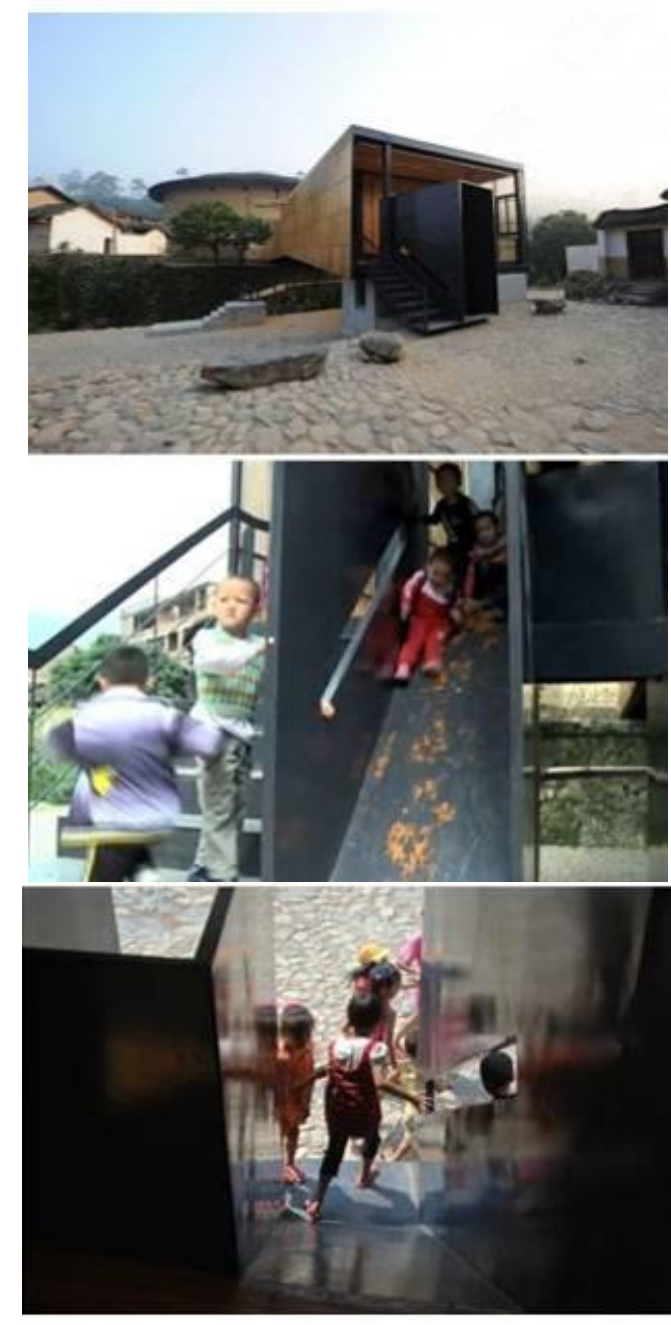

Gambar 8. Kulit bangunan dijadikan sekaligus elemen arsitektur maupun elemen interior untuk menghubungkan kegiatan bermain anak-anak di dalam dan di luar bangunan.

Sumber: http://www.archdaily.com/45409/schoolbridge-xiaodong-lii, diunduh 3 November 2014

\section{Kesimpulan}

\section{Simpulan}

Dari kajian literatur serta eksplorasi studi kasus yang telah dibahas, maka dapat disimpulkan bahwa desain interior seharusnya memiliki peran yang jauh lebih signifikan dan mutahir daripada hanya sekedar pengisi atau ahli dekorasi di dalam batasan arsitektur. Mendukung pendapat yang disebut oleh Cys (2009) tentang 
karakter inter-discplinary dari interior, maka kreativitas dan pengolahan desain bangunan bisa lebih terbuka terhadap perlintasan bidang ilmu baik secara fisik maupun konseptual. Hal ini memungkinan terciptanya pengembangan elemen-elemen interior maupun arsitektur yang baru seiring dengan berkembangnya kompleksitas kehidupan manusia dan perubahan lingkungan. Sebagai upaya untuk memberikan gambaran nyata bagaimana pemahaman interior sebagai "penghubung" dapat dipraktekan, beberapa teknik olah desain yang dapat digunakan adalah pengaburan batas fisik, manipulasi programatik, inovasi kontinuitas material serta konfigurasi elemen arsitektur menjadi elemen interior.

\section{Saran}

Melihat kecenderungan praktik desain interior dan arsitektur di Indonesia yang bekerja secara terpisah baik secara fisik maupun konseptual, maka diperlukan kajian ulang peran desain interior maupun arsitektur dalam dunia akademik maupun profesional. Hasil dari kajian ini diharapkan dapat menjadi materi pertimbangan dalam menyusun kurikulum akademik serta panduan praktik desain interior maupun arsitektur di masa depan. Sebagai salah satu contoh, kurikulum pendidikan desain interior memerlukan pengantar mengenai esensi ilmu arsitektur yang bersifat makro sebelum mempelajari bagian interior yang mikro ke arah detail. Sebaliknya, kurikulum pendidikan arsitektur juga perlu memberikan tambahan keahlihan atau mata kuliah khusus mengenai desain interior.

Dengan ilmu memanipulasi ruang secara fisik maupun konseptual yang berlintas bidang, lingkup desain interior tidak lagi menjadi sekedar pengisi ruang dan juga tidak terbatasi oleh struktur arsitektur melainkan sebuah bidang ilmu yang memiliki peran yang sangat penting dalam memelihara hubungan manusia dengan lingkungan hidupnya.

\section{Daftar Pustaka}

Caan, S. (2011). Rethinking design and interiors. London: Laurence King Publishing.

Cai, Y. (2010). Chinese architecture: Palaces, gardens, temples and dwellings. Beijing: China Intercontinental Press.

Cys, J. (2009). Finding a space for the practice of interior design. Dalam Lee, Gini (Ed) Interior territories: Exposing the critical interior. Queensland University of Technology: IDEA Journal, 84-95.

Grosz, E. (2001). Architecture from the outside: Eessays on virtual and real Space. Cambridge, Massachusetts: MIT.

Li, X. dan Yang, K. S. (2007). The chinese conception of space. Beijing: China Architecture and Building Press.

Lou, Q. (2010). Chinese gardens. In search of landscape paradise. Beijing: China Intercontinental Press.

Moleong, L. J. (2013). Metodologi penelitian kualitatif, edisi revisi, Bandung: PT. Remaja Rosdakarya.

Pile, J. F. (2015). A history of interior design, $3^{\text {rd }}$ edition. London: Laurence King Publishing, 305-327.

Pimlot, M. (2009). Only within. Dalam Lee, G. (Ed) Interior territories: Exposing the critical interior. Queensland University of 
Technology: IDEA Journal, 8495.

Smith, C. (2004). Inside-out: Speculating on the interior. IDEA Journal, 5, 93-102.

Whiton, S. dan Abercombie, S. (2002). Interior design and decoration Fifth Edition. Upper Sadle River, N.J: Prentice Hall. 